\title{
Silicon Deposition in Leaf Trichomes of Cucurbitaceae Horticultural Plants: A Short Report
}

\author{
Jun Abe \\ Department of Plant Science, School of Agriculture, Tokai University, Kumamoto, Japan \\ Email: abejun@agri.u-tokai.ac.jp
}

How to cite this paper: Abe, J. (2019) Silicon Deposition in Leaf Trichomes of Cucurbitaceae Horticultural Plants: A Short Report. American Journal of Plant Sciences, 10, 486-490.

https://doi.org/10.4236/ajps.2019.103034

Received: February 27, 2019

Accepted: March 22, 2019

Published: March 25, 2019

Copyright (อ 2019 by author(s) and Scientific Research Publishing Inc. This work is licensed under the Creative Commons Attribution International License (CC BY 4.0).

http://creativecommons.org/licenses/by/4.0/

\section{(c) (i) Open Access}

\begin{abstract}
Silicon deposition in leaf trichome of six horticultural Cucurbitaceae species, cucumber (Cucumis sativus), pumpkin (Cucurbita maxima), melon (Cucumis melo), watermelon (Citrullus lanatus), sponge gourd (Luffa cylindrica) and bottle gourd (Lagenaria siceraria var. hispida) was observed by an X-ray microanalyzer coupled with an environmental scanning electron microscope. The elements that presented in the surface of three or four leaves of the individual species were detected and mapped by the X-ray microanalyzer. In leaves of cucumber, pumpkin, and melon, high accumulation of silicon was detected in cells surrounding the bases of the trichome hair and the hair itself deposited calcium. On the other hand, in sponge gourd and bottle gourd, high accumulation of silicon was detected only in the hair. In watermelon leaves, silicon deposited both in the hair and in cells surrounding the bases of the hair. Thus, horticultural Cucurbitaceae plants have interspecific variation in the pattern of silicon deposition in leaf trichomes.
\end{abstract}

\section{Keywords}

Bottle Gourd (Lagenaria siceraria var. hispida), Leaf Trichome, Melon (Cucumis melo), Pumpkin (Cucurbita maxima), Silicon Accumulation, Sponge Gourd (Luffa cylindrica), Watermelon (Citrullus lanatus)

\section{Introduction}

Although silicon ( $\mathrm{Si}$ ) has not been recognized as an essential nutrient for many plants, some plants (such as Poaceae plants) accumulate substantial amount of silicon in specific tissues of leaf and root [1]. For instance, many of Poaceae plants deposit silicon in the cell wall of leaf epidermis and root endodermis [1] [2] [3] [4] [5]. The silicon accumulated in Poaceae plants is thought to contri- 
bute to intensity of leaf and root, tolerance to various types of environmental stresses and protection against insects and diseases [1] [6] [7] [8] [9].

As well as Poaceae plants, Cucurbitaceae plants such as cucumber (Cucumis sativus) and pumpkin (Cucurbita moschata) roots have silicon transporter and absorb silicon from soil medium to plant body [10] [11] [12] [13]. Cucumber plants deposit silicon in cells surrounding the base of the leaf trichome hair [14] [15]. Samuels et al. (1991) pointed that the silicon in cucumber leaf suppressed the growth of powdery mildew fungus (Sphaerotheca fuliginea), which is the pathogen of major cucumber disease [14].

In other Cucurbitaceae plants, however, information of silicon accumulation and deposition is limited. Examination of silicon deposition in leaf surface in horticulturally important species may contribute to understand the role of silicon in tolerance and resistance of the species to environmental stresses and diseases. In this study, leaf surface of five Cucurbitaceae species was observed by an environmental scanning electron microscope and the silicon accumulation was analyzed by an X-ray microanalyzer to compare the silicon deposition patterns in and around leaf trichome hair with cucumber plants.

\section{Materials and Methods}

Six horticultural Cucurbitaceae species, cucumber (Cucumis sativus), pumpkin (Cucurbita maxima), melon (Cucumis melo), watermelon (Citrullus lanatus), sponge gourd (Luffa cylindrica) and bottle gourd (Lagenaria siceraria var. hispi$d a)$, were grown with conventional cultivation management in open farm fields of the experimental farm of the University of Tokyo (Nishi-tokyo City, Tokyo, Japan) in 2008. The top soil (0 - $30 \mathrm{~cm}$ deep) of the fields was Andosol, and the subsoil was Kanto Loam. Because no silicon fertilizer or irrigation water was applied to the plants, the source of silicon in the grown plants was natural silicon in soil and rainfall water.

Fresh green fully-expanded leaves of the plants were collected and observed by an environmental scanning electron microscope (Nikon ESEM 2700) without chemical treatment such as fixation and coating. Four sites of leaf surface in both adaxial and abaxial sides cut out of three or four leaf blades of the individual species were examined. Silicon and calcium distribution was mapped using the X-ray microanalyzer (Philips EDAX DX4) coupled with the ESEM. The working conditions of EDAX were as follows [5]: accelerating voltage $15 \mathrm{kV}$, pressure 520 $\mathrm{Pa}$, working distance $8 \mathrm{~mm}$, tilt $30^{\circ}$, and take-off angle $43.2^{\circ}$. The imaging gas used in the ESEM was water vapor. For the mapping, $400 \times$ magnification was employed.

\section{Results and Discussion}

Silicon distributed all over the leaf surface in both adaxial and abaxial sides, and high accumulation of silicon was observed in and/or around trichome hairs in the six species of Cucurbitaceae (Figure 1). 

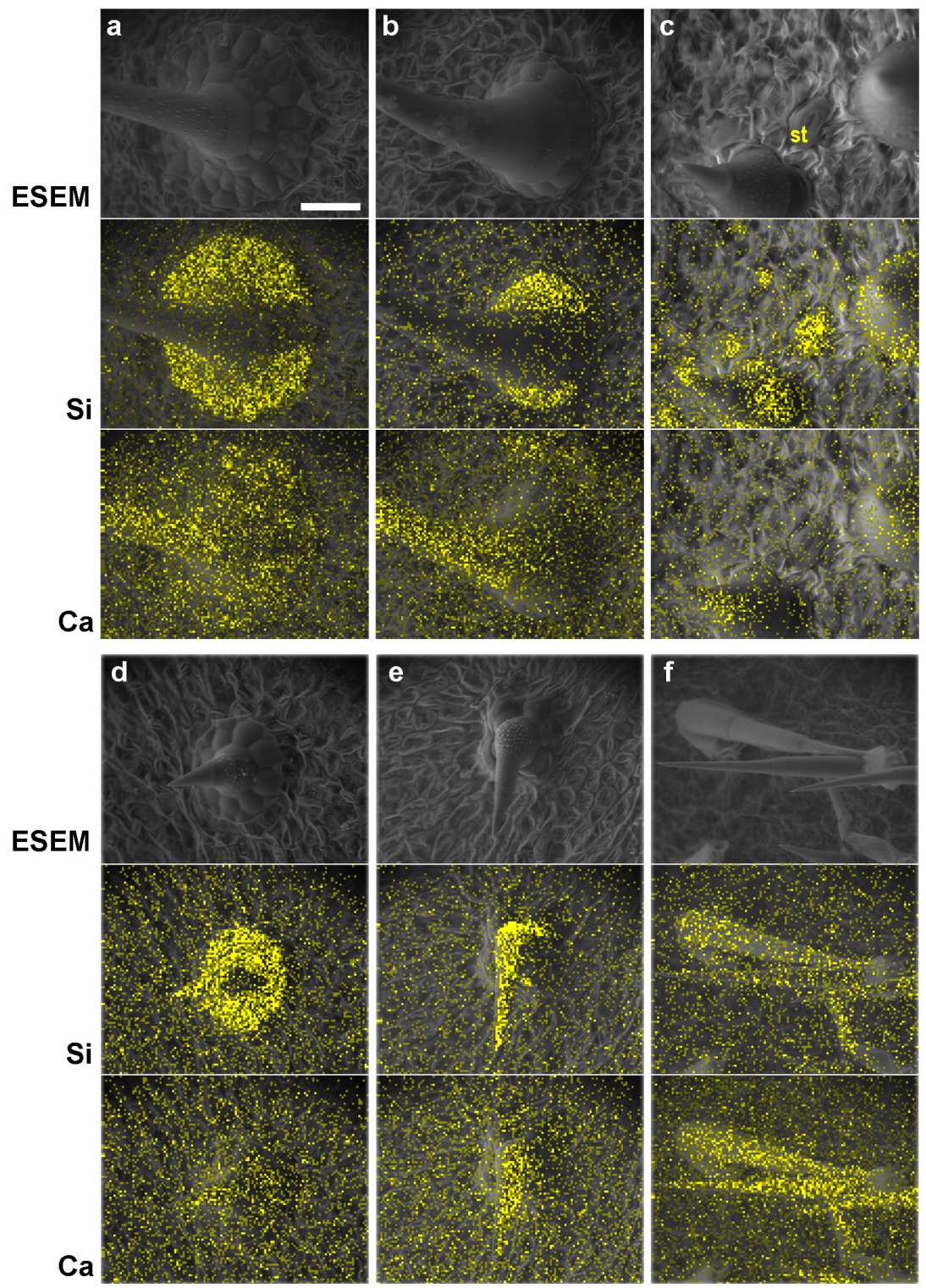

Figure 1. ESEM image, silicon distribution and calcium distribution around leaf trichome. (a) Cucumber, (b) Pumpkin, (c) Melon, (d) Watermelon, (e) Sponge gourd, (f) Bottle gourd. Yellow dots indicate the presence of silicon or calcium. The white bar indicates $100 \mu \mathrm{m}$. st: stomata.

In cucumber leaves, silicon was highly accumulated in cells surrounding the bases of the trichome hair (Figure 1(a)) as it was reported by previous studies [14] [15]. In pumpkin and melon leaves as well as cucumber leaves, silicon was highly accumulated in cells surrounding the bases of the trichome hair (Figure 1(b) \& Figure 1(c)). In the hair itself, instead of silicon, calcium was deposited. Thus, the intensity of leaf trichomes of these three plants is raised by the combination of calcium in hair and silicon in the base of hair. In watermelon leaf, silicon was highly deposited in both hair itself and in cells surrounding the bases of the hair (Figure 1(d)).

On the other hand, in both sponge gourd and bottle gourd, high accumulation 
of silicon was detected only in hair itself (Figure 1(e) \& Figure 1(f)). As the cells surrounding the bases of the trichome hair of sponge gourd and bottle gourd were not stiffened by silicon or calcium, the trichomes of these two species tended to bend at the base in low-vacuum state of ESEM.

For the movement and transportation of silicon in plant tissues, silicon transporter is needed [10] [11] [12] [13]. The variation of silicon and calcium deposition in leaf trichomes among the Cucurbitaceae species should reflect the difference in the site of influx silicon-transporter expression.

It should be noted that some of the stomatal guard cells in melon leaves also deposited silicon (Figure 1(c)). Ueno and Agarie (2005) reported the deposition of silicon in rice stomatal guard cells [16]. They suggested that the silicon has some mechanical and physiological role in stomatal apparatus and that silicon deposition may decrease evaporation water loss [16]. In melon leaf, the deposition of silicon in stomatal guard cells may have the same role.

\section{Conclusion}

The horticultural Cucurbitaceae plants examined in this study showed interspecific difference in the pattern of silicon accumulation at leaf trichome. Sponge gourd and bottle gourd, which did not deposited silicon in the cells surrounding the bases of the trichome hair, indicated low strength of trichome. The difference in silicon accumulation pattern may affect the tolerance and resistance of the individual species to biotic and abiotic environmental stresses.

\section{Conflicts of Interest}

The author declares no conflicts of interest regarding the publication of this paper.

\section{References}

[1] Ma, J.F. and Takahashi, E. (2002) Soil, Fertilizer, and Plant Silicon Research in Japan. Elsevier, Amsterdam.

[2] Bennett, D.M. (1982) Silicon Deposition in the Roots of Hordeum sativum Jess., Avena sativa L. \& Triticum aestivum L. Annals of Botany, 50, 239-245. https://doi.org/10.1093/oxfordjournals.aob.a086361

[3] Hodson, M.J. (1986) Silicon Deposition in the Roots, Culm and Leaf of Phalaris canariensis L. Annals of Botany, 58, 167-177. https://doi.org/10.1093/oxfordjournals.aob.a087194

[4] Lux, A., Luxová, M., Morita, S., Abe, J. and Inanaga, S. (1999) Endodermal Silicification in Developing Seminal Roots of Lowland and Upland Cultivars of Rice (Oryza sativa L.). Canadian Journal of Botany, 77, 955-960. https://doi.org/10.1139/b99-043

[5] Lux, A., Miroslava Luxová, M., Abe, J., Tanimoto, E., Hattori, T. and Inanaga, S. (2003) The Dynamics of Silicon Deposition in the Sorghum Root Endodermis. New Phytologist, 158, 437-441. https://doi.org/10.1046/j.1469-8137.2003.00764.x

[6] Ahmad, R., Zaheer, S.H. and Ismail, S. (1992) Role of Silicon in Salt Tolerance of Wheat (Triticum aestivum L.). Plant Science, 85, 43-50. 
https://doi.org/10.1016/0168-9452(92)90092-Z

[7] Hammond, K.E., Evans, D.E. and Hodson, M.J. (1995) Aluminium/Silicon Interactions in Barley (Hordeum vulgare L.) Seedlings. Plant and Soil, 173, 89-95. https://doi.org/10.1007/BF00155521

[8] Liang, Y., Shen, Q., Shen, Z. and Ma, T. (1996) Effects of Silicon on Salinity Tolerance of Two Barley Cultivars. Journal of Plant Nutrition, 19, 173-183. https://doi.org/10.1080/01904169609365115

[9] Hattori, T., Inanaga, S., Araki, H., An, P., Morita, S., Luxová, M. and Lux, A. (2005) Application of Silicon Enhanced Drought Tolerance in Sorghum bicolor. Physiologia Plantarum, 123, 459-466. https://doi.org/10.1111/j.1399-3054.2005.00481.x

[10] Liang, Y., Si, J. and Römheld, V. (2005) Silicon Uptake and Transport Is an Active Process in Cucumis sativus. New Phytologist, 167, 797-804. https://doi.org/10.1111/j.1469-8137.2005.01463.x

[11] Ma, J.F. and Yamaji, N. (2006) Silicon Uptake and Accumulation in Higher Plants. Trends in Plant Science, 11, 392-397. https://doi.org/10.1016/j.tplants.2006.06.007

[12] Ma, J.F. and Yamaji, N. (2008) Functions and Transport of Silicon in Plants. Cellular and Molecular Life Sciences, 65, 3049. https://doi.org/10.1007/s00018-008-7580-x

[13] Ueno, N.M., Yamaji, N. and Ma, J.F. (2011) Silicon Efflux Transporters Isolated from Two Pumpkin Cultivars Contrasting in Si Uptake. Plant Signaling and Behavior, 6, 991-994. https://doi.org/10.4161/psb.6.7.15462

[14] Samuels, A.L., Glass, A.D.M., Ehret, D.L. and Menzies, J.G. (1991) Distribution of Silicon in Cucumber Leaves during Infection by Powdery Mildew Fungus (Sphaerotheca fuliginea). Canadian Journal of Botany, 69, 140-146. https://doi.org/10.1139/b91-020

[15] Samuels, A.L., Glass, A.D.M., Ehret, D.L. and Menzies, J.G. (1991) Mobility and Deposition of Silicon in Cucumber Plants. Plant Cell and Environment, 14, 485-492. https://doi.org/10.1111/j.1365-3040.1991.tb01518.x

[16] Ueno, O. and Agarie, S. (2005) Silica Deposition in Cell Walls of the Stomatal Apparatus of Rice Leaves. Plant Production Science, 8, 71-73.

https://doi.org/10.1626/pps.8.71 